\title{
Performance and carcass traits of Nellore cattle fattening on pasture receiving different zinc contents in the mineral supplementation
}

\author{
Desempenho produtivo e características de carcaça de bovinos \\ Nelore em regime de engorda a pasto recebendo diferentes teores de \\ zinco na suplementação mineral
}

\author{
Julliano Percinoto Pompei ${ }^{1}$; Geisi Loures Guerra ${ }^{2 *}$; Elzânia Sales Pereira ${ }^{3}$; \\ Leandro das Dores Ferreira da Silva ${ }^{4}$; Patrícia Guimarães Pimentel ${ }^{3}$; Edson Luis de \\ Azambuja Ribeiro ${ }^{4}$; Taís Aline Bregion dos Santos ${ }^{5}$; Angelita Xavier dos Santos ${ }^{5}$; \\ Mariellen Cristine Andrade Ribeiro ${ }^{6}$; Ivone Yurika Mizubuti ${ }^{4}$
}

\begin{abstract}
The objective of this work was to study the effect of different zinc content $\left(\mathrm{ZnSO}_{4}\right)$ in the mineral supplementation for Nellore steers grazing Brachiaria brizantha (cv) MG-4, on productive performance and carcass traits. Twenty-eight castrated animals with average body weight of $355 \mathrm{~kg}$, were used. The animals were randomly divided into four groups and housed in paddocks of 6.25 ha each one, equipped with covered feeders and waterers, and grazed alternately each 28 days. The experimental design was completely randomized, with four zinc $(\mathrm{Zn})$ content and seven repetitions. Different zinc content were: $\mathrm{Zn}-0$, without $\mathrm{Zn}$; Zn-2, with 2,000 mg Zn kg-1; Zn-4, with 4,000 $\mathrm{mg} \mathrm{Zn} \mathrm{kg}^{-1}$; and Zn-6, with 6,000 mg $\mathrm{Zn} \mathrm{kg}^{-1}$; in the inorganic form (Zinc Sulphate) in mineral supplement. Mineral supplements were given ad libitum in covered troughs and previously weighed, with leftovers control for determining intake. The experimental period was 370 days. Organs, viscera, carcass and non-carcass components were weighed from each slaughtered animal. Loin eye area (LEA) and subcutaneous fat thickness (SFAT), as well as, color, $\mathrm{pH}$ and lipid oxidation, were evaluated. The increasing inclusion of zinc content in the diet of steers do not affected $(\mathrm{P}>0.05)$ final body weight $(\mathrm{FBW})$ and average daily weight gain $(\mathrm{ADWG})$. Difference $(\mathrm{P}<0.05)$ was observed in the $\mathrm{Zn}$ intake $(\mathrm{ZnI})\left(\hat{\mathrm{Y}}=-2.09386+146.9616 \mathrm{x} ; \mathrm{R}^{2}=\right.$ $0.99)$ and hot carcass weight $\left(\hat{Y}=299.92662+3.33362 x ; R^{2}=0.24\right)$, as well as, in meat lipid oxidation $\left(\hat{Y}=0.15170+0.02539 x ; R^{2}=0.31\right)$. There was an increasing linear effect for meat color, evaluated by values of $L^{*}$ (luminosity) $\left(\hat{Y}=32.23309+0.41445 x, R^{2}=0.14\right)$, $a^{*}$ (red-green intensity) $(\hat{Y}=$ $\left.0.88592+18.16225 \mathrm{x}, \mathrm{R}^{2}=0.25\right)$ and $\mathrm{b}^{*}$ (yellow-blue intensity) $\left(\hat{\mathrm{Y}}=9.35295+0.45030 \mathrm{x}, \mathrm{R}^{2}=0.20\right)$, but remained within normal values for meat. It can be concluded that beef cattle grazing Brachiaria brizantha MG-4, and supplemented with different zinc contents in mineral supplements, supplied ad libitum, do not show changes in weight gain, carcass yield, physical carcass composition, as well as,
\end{abstract}

\footnotetext{
${ }^{1}$ Médico Veterinário, M.e em Ciência Animal, Universidade Estadual de Londrina, UEL, Londrina, PR, Brasil. E-mail: jullianopompei@hotmail.com

2 Discente, Curso de Doutorado do Programa de Pós-Graduação em Ciência Animal, UEL, Londrina, PR, Brasil. E-mail: geisi_ guerra@hotmail.com

3 Prof ${ }^{\mathrm{a}} \mathrm{Dr}^{\mathrm{a}}$, Departamento de Zootecnia, Universidade Federal do Ceará, UFC, Ceará, CE, Brasil. E-mail: elzania@hotmail.com; pgpimentel@hotmail.com

4 Profs. Drs., Departamento de Zootecnia, UEL, Londrina, PR, Brasil. E-mail: leandro@uel.br; elar@uel.br; mizubuti@uel.br

5 Médicas Veterinárias e Zootecnistas, Dr ${ }^{\text {as }}$ em Ciência Animal, UEL, Londrina, PR, Brasil. E-mail: taisbregion@gmail.com; xavier@zootecnista.com.br

6 Discente, Curso de Mestrado do Programa de Pós-Graduação em Ciência Animal, UEL, Londrina, PR, Brasil. E-mail: mariellen. andrade@hotmail.com

* Author for correspondence
} 
in non-carcass components, but the $\mathrm{Zn}$ content has a positive linear influence on hot carcass weight, without causing changes in absolute and relative weights of organs and viscera.

Key words: Intake. Non-carcass component. Organs and viscera. Ruminants. Weight gain.

\section{Resumo}

Objetivou-se estudar o efeito de diferentes teores de Zinco na suplementação mineral de novilhos Nelore em pastagem de Brachiaria brizantha cultivar (cv) MG-4, sobre o desempenho produtivo e características de carcaça. Foram utilizados 28 animais, castrados, com peso vivo médio inicial de 355 $\mathrm{kg}$. Os animais foram divididos ao acaso em quatro grupos e alojados em piquetes de 6,25 hectares cada, equipados com comedouro coberto e bebedouros, sendo pastejados alternadamente a cada pesagem (28 dias). O delineamento experimental foi inteiramente casualizado, com quatro dosagens de zinco (Zn) no suplemento mineral e sete repetições. As doses de zinco avaliadas foram: $\mathrm{Zn}-0$, sem adição de Zinco; Zn-2, com 2.000 mg de Zn kg-1; Zn-4, com 4.000 mg de Zn kg-1; e Zn-6, com 6.000 mg de Zn $\mathrm{kg}^{-1}$; sob forma inorgânica (Sulfato de Zinco) no suplemento mineral. Os suplementos minerais foram pesados e fornecidos ad libitum, em cochos cobertos, com controle das sobras para determinação do consumo. O período experimental foi de 370 dias. De cada animal abatido pesaram-se órgãos, vísceras, carcaça e componentes não carcaça. Avaliaram-se a área de olho de lombo (AOL) e espessura da gordura subcutânea (EGSC), bem como a cor, $\mathrm{pH}$ e oxidação lipídica. A crescente inclusão do zinco na dieta dos bovinos, não influenciou $(\mathrm{P}>0,05)$ o peso vivo final $(\mathrm{PVF})$ e o ganho de peso médio diário (GPMD). Observou-se diferença $(\mathrm{P}<0,05)$ no consumo de $\mathrm{Zn}(\mathrm{CZn})(\hat{\mathrm{Y}}=-2,09386+146,9616 \mathrm{x}$; $\left.\mathrm{R}^{2}=0,99\right)$ e peso de carcaça quente $\left(\hat{\mathrm{Y}}=299,92662+3,33362 \mathrm{x}, \mathrm{R}^{2}=0,24\right)$, bem como na oxidação lipídica da carne $\left(\hat{Y}=0,15170+0,02539 x ; R^{2}=0,31\right)$. Houve efeitos lineares crescentes sobre a cor da carne, avaliados pelos valores de " $L$ *" (luminosidade) $\left(\hat{Y}=32,23309+0,41445 x ; R^{2}=0,14\right)$, "a*" (intensidade de vermelho-verde) $\left(\hat{\mathrm{Y}}=0,88592+18,16225 \mathrm{x}, \mathrm{R}^{2}=0.25\right) \mathrm{e}$ " $\mathrm{b} *$ " (intensidade de amareloazul) $\left(\hat{Y}=9,35295+0,45030 x ; R^{2}=0,20\right)$, porém mantiveram-se dentro dos valores normais para carne bovina. Pode-se concluir que bovinos mantidos em pastagens e recebendo diferentes doses de zinco em suplementos minerais, fornecidos ad libitum, não sofrem influência no ganho de peso, rendimento de carcaça, composição físicas das carcaças, assim como nos componentes não carcaça, mas o $\mathrm{Zn}$ exerce influencia linear positiva sobre o peso de carcaça quente, sem causar alterações nos pesos relativos e absolutos de órgão e vísceras.

Palavras-chave: Componente não carcaça. Consumo. Ganho de peso. Órgãos e vísceras. Ruminantes.

\section{Introduction}

The beef cattle industry is developed in all Brazilian states and is an important economic activity with major role in the trade balance of the country (EUCLIDES FILHO; EUCLIDES, 2010).

In a general way, on tropical regions, the cattle get the most part of nutrients (energy, protein, minerals and vitamins) required from forage. According to Silva and Baruselli (2001), studies in the University of Florida using 2,615 samples of forage from Latin America, showed that $43 \%$ of the samples were deficient in cobalt, $47 \%$ in copper,
$35 \%$ in magnesium, $73 \%$ in phosphorus, $60 \%$ in sodium and $75 \%$ in zinc $(\mathrm{Zn})$, for livestock feeding.

The ad libitum intake of minerals is the most common way to deliver minerals to cattle grazing. The complete mineral mix usually includes common salt and the phosphorus source, in addition to calcium, cobalt, copper, iodine, iron and zinc. However, in tropical regions of acidic soil, the manganese and iron can be eliminated from the mixture (CARVALHO et al., 2005).

On regions with tropical weather where there is predominance of vegetation of the type Brazilian 
cerrado and soils with low fertility, the $\mathrm{Zn}$ has received special attention, due to his low content found on the mineral profile of different forage used in livestock production. The requirements for zinc in beef cattle are around $30 \mathrm{mg} \mathrm{Zn} \mathrm{kg}^{-1}$ of dry matter for all categories of animals (MORAES, 2001).

One of the first symptoms which arise in zinc deficiency is the reduction of appetite, up to $60 \%$ of cases. Associated to this fact occurs the progressive weight loss, because the growth factor levels (Insulin-like growth factor 1 - IGF1) are reduced, and the incorporation of nitrogen to tissue becomes lowered due to increased excretion of this component by urine (ORTOLANI; SUCUPIRA, 2010).

The insertion of available technologies in the beef production chain could result in substantial impact on beef cattle production and on competitiveness of the various segments of the chain of meat production (EUCLIDES FILHO; EUCLIDES, 2010).

Zinc as an essential trace element to the animal production system and has been extensively studied in other countries, but the research in Brazil are still insufficient. The enzymes that require $\mathrm{Zn}$ are involved in the nucleic acids, proteins and carbohydrates metabolism and, consequently, cell metabolism, emphasizing their importance for normal functioning of the immune system. In addition, the amino acid requirement in protein synthesis is injured by Zn deficiency, which justifies its great importance on animal performance (CRUZ; SOARES, 2011).

Zinc deficiency among other factors, results in the reduction of GH (growth hormone) receptor and the consequent decrease in IGF-1 (insulinlike growth factor 1) reducing the release of the neuropeptide, and appetite loss (SALGUEIRO et al., 1999). Numerous enzymes that are involved in DNA and RNA synthesis process are zinc metalloenzymes dependent, which may influence the hormonal regulation of cell division, especially pathway GH and IGF-1 besides to interfere with mitogenic hormones acting on cell proliferation (SENA; PEDROSA, 2005). Zinc is component of superoxide dismutase enzyme ( $\mathrm{Cu}-\mathrm{ZnSOD}$ ) having as an active center a zinc ion present in the cytoplasm of all cells. The $\mathrm{Cu}-\mathrm{ZnSOD}$ action is to catalyze the conversion of superoxide $\left(\mathrm{O}_{2}^{-}\right)$ in hydrogen peroxide and oxygen (LEHNINGER et al., 2006), while glutathione peroxidase (GSHPx) removes hydrogen peroxide by transforming them in water, neutralizing the oxidizing action of peroxides (VÁZQUEZ-AÑÓN et al., 2008).

The objective of this study was to evaluate the effect of different zinc content in mineral supplementation on productive performance and carcass traits of beef cattle on pasture.

\section{Material and Methods}

The experiment was conducted at the farm of the Matsuda Group, located in the municipality of "Mirante do Paranapanema" (SP) around 230 km far from Londrina (PR). The geographic coordinates are $22^{\circ} 16^{\prime} 03.33$ "S and $51^{\circ} 46^{\prime} 46.69$ " W; 440 meter height from sea level; annual average temperature of $22.8^{\circ} \mathrm{C}$ and pluviometric index of $1,298 \mathrm{~mm}$ year 1 .

The experiment lasted 370 days. Twenty-eight steers, male, castrated, Nelore breed, aged 30 months and initial mean live weight of $355 \mathrm{~kg}$ were used. The animals were previously weighed (after 16 hours solids fasting), identified with numbers in the right leg, vaccinated against foot and mouth disease and submitted to the endo and ectoparasites control. Then, they were randomly distributed in four groups and housed in paddocks of 6.25 hectares each, with Brachiaria brizantha cv. MG-4, all equipped with covered feeders and drinkers, where they were grazed alternately in each weighing (28 days). The annual average stocking rate was $1.14 \mathrm{AU} \mathrm{ha}^{-1}$.

Samples of Brachiaria brizantha cv. MG-4 were harvested from the pasture, every 28 days, 
for chemical analysis and determination of mineral contents. For the sampling of Brachiaria brizantha cv. MG-4, the grazing by the animals was simulated, taking care to avoid feces and bed grounds of the animals.
The chemical and mineral analysis of the forage (Table 1) were carried out in the animal nutrition laboratory of the company Comércio e Indústria Matsuda Importadora e Exportadora Ltda, in Álvares Machado - SP.

Table 1. Average chemical and mineral composition of Brachiaria brizantha cv. MG-4, according to the season of the year.

\begin{tabular}{|c|c|c|c|c|c|c|}
\hline & & & Yea & & & \\
\hline & & Spring & Summer & Fall & Winter & Average \\
\hline Dry Matter & $\left(\mathrm{g} \mathrm{kg}^{-1}\right)$ & 274.1 & 258.1 & 308.2 & 335.1 & 293.9 \\
\hline Mineral Mater & $\left(\mathrm{g} \mathrm{kg}^{-1}\right)$ & 89.3 & 95.8 & 73.0 & 68.4 & 81.6 \\
\hline Crude Fiber & $\left(\mathrm{g} \mathrm{kg}^{-1}\right)$ & 363.1 & 371.6 & 377.3 & 380.5 & 373.1 \\
\hline Ether Extract & $\left(\mathrm{g} \mathrm{kg}^{-1}\right)$ & 16.9 & 16.7 & 15.5 & 13.7 & 15.7 \\
\hline Crude Protein & $\left(\mathrm{g} \mathrm{kg}^{-1}\right)$ & 83.7 & 102.3 & 74.5 & 65.3 & 81.5 \\
\hline $\mathrm{NNE}^{1}$ & $\left(\mathrm{~g} \mathrm{~kg}^{-1}\right)$ & 44.70 & 41.36 & 45.97 & 47.21 & 44.81 \\
\hline TDN Estimated ${ }^{2}$ & $\left(\mathrm{~g} \mathrm{~kg}^{-1}\right)$ & 535.3 & 530.6 & 528.8 & 524.7 & 530.5 \\
\hline NDF & $\left(\mathrm{g} \mathrm{kg}^{-1}\right)$ & 762.0 & 751.0 & 777.8 & 768.5 & 764.8 \\
\hline $\mathrm{ADF}$ & $\left(\mathrm{g} \mathrm{kg}^{-1}\right)$ & 413.5 & 384.8 & 425.8 & 406.7 & 407.7 \\
\hline Phosphorus, P & $\left(\mathrm{g} \mathrm{kg}^{-1}\right)$ & 2.75 & 2.9 & 2.25 & 2.8 & 2.68 \\
\hline Potassium, K & $\left(\mathrm{g} \mathrm{kg}^{-1}\right)$ & 26.6 & 22 & 18.05 & 21.35 & 22.00 \\
\hline Calcium, $\mathrm{Ca}$ & $\left(\mathrm{g} \mathrm{kg}^{-1}\right)$ & 6.45 & 6.3 & 7.15 & 6.2 & 6.53 \\
\hline Magnesium, Mg & $\left(\mathrm{g} \mathrm{kg}^{-1}\right)$ & 4.45 & 3.95 & 5.65 & 5.15 & 4.80 \\
\hline Sulfur, S & $\left(\mathrm{g} \mathrm{kg}^{-1}\right)$ & 1.0 & 0.97 & 1.05 & 0.94 & 0.99 \\
\hline Boron, B & $\left(\mathrm{mg} \mathrm{kg}^{-1}\right)$ & 19.0 & 21.0 & 18.5 & 18.0 & 19.13 \\
\hline Copper, $\mathrm{Cu}$ & $\left(\mathrm{mg} \mathrm{kg}^{-1}\right)$ & 13.0 & 12.0 & 11.5 & 11.0 & 11.88 \\
\hline Iron, $\mathrm{Fe}$ & $\left(\mathrm{mg} \mathrm{kg}^{-1}\right)$ & 85.0 & 114.5 & 116 & 96.5 & 103.0 \\
\hline Manganese, Mn & $\left(\mathrm{mg} \mathrm{kg}^{-1}\right)$ & 47.5 & 95.5 & 78.5 & 103.5 & 81.25 \\
\hline Zinc, Zn & $\left(\mathrm{mg} \mathrm{kg}^{-1}\right)$ & 31.5 & 29.5 & 32 & 32.5 & 31.38 \\
\hline
\end{tabular}

$\mathrm{NDF}=$ Neutral detergent fiber; $\mathrm{ADF}=$ Acid detergent fiber; $\mathrm{NNE}=$ non-nitrogenous extract.

${ }^{1}$ Calculated by formula: NNE = $100-$ CP - CF - EE - MM, described by Mizubuti et al. (2009).

${ }^{2}$ Calculated by McDowell et al. (1974).

To determine the chemical composition of the forage, the methods described by Mizubuti et al. (2009) were used. Total digestible nutrient values (TDN) were estimated according to McDowell et al. (1974), using the following equation: $\mathrm{TDN}=$ $72.943+4.75 *(\mathrm{CF})-1.28 *(\mathrm{EE})+1.611 *(\mathrm{NNE})$ $+0.497 *(\mathrm{CP})-0.044 *(\mathrm{CF})^{2}-0.76 *(\mathrm{EE})^{2}-$
$0.039 *(\mathrm{CF}) *(\mathrm{NNE})+0.087 *(\mathrm{EE}) *(\mathrm{NNE}) \quad-$ $0.152 *(\mathrm{EE}) *(\mathrm{CP})+0.074 *(\mathrm{EE})^{2 *}(\mathrm{CP})$.

For determination of the mineral content of the forage, the methodology of metals analysis using spectrophotometry of atomic absorption was used, according to the recommendation of AOAC (1990). 
The experimental design was completely randomized, comprising mineral supplements with four different zinc contents (Zn) and seven replicates. The zinc contents evaluated were: $\mathrm{Zn}-0$, without Zinc addition; Zn-2, with 2,000 $\mathrm{mg} \mathrm{Zn} \mathrm{kg}^{-1}$; Zn-4, with 4,000 $\mathrm{mg} \mathrm{Zn} \mathrm{kg}^{-1}$ and Zn-6, with 6,000 mg $\mathrm{Zn} \mathrm{kg}{ }^{-1}$, on inorganic form of Zinc Sulfate $\left(\mathrm{ZnSO}_{4}\right)$, supplied to the animals in mineral supplement of ready utilization. The period of adaptation of the animals to the mineral supplements and the conditions of handling was 30 days.

The mineral supplement, formulated according to recommendations of NRC (2000) (Table 2) was weighed and supplied ad libitum to the animals in covered troughs and the consumption by the animals was monitored by control of leftovers and replacement of the same in the troughs.

The animals were weighed every 28 days, after fasting for solid food for 16 hours. Then, the animals were rotated to receive supplements with different zinc contents in the paddocks, called Paddocks A, B, $\mathrm{C}$ and $\mathrm{D}$, always changing in a clockwise direction, thus allowing all the animals receiving different zinc contents to graze in all of the paddocks in the course of the experiment. At each rotation, the salt troughs were cleaned for paddocks exchange and mineral supplements, thus avoiding contamination between the supplements.

Table 2. Composition of the mineral supplements with different levels of zinc used during the experimental period.

\begin{tabular}{|c|c|c|c|c|}
\hline \multirow{3}{*}{ Components } & \multicolumn{4}{|c|}{ Mineral Supplement $^{1}$} \\
\hline & \multicolumn{4}{|c|}{ (Guarantee levels per quilogram of product) } \\
\hline & $\mathrm{Zn}-0$ & $\mathrm{Zn}-2$ & $\mathrm{Zn}-4$ & $\mathrm{Zn}-6$ \\
\hline Calcium (Max.) $\left(\mathrm{g} \mathrm{kg}^{-1}\right)$ & 120 & 120 & 120 & 120 \\
\hline Calcium (Min.) ( $\left.\mathrm{g} \mathrm{kg}^{-1}\right)$ & 105 & 105 & 105 & 105 \\
\hline Phosphorus (Min.) $\left(\mathrm{g} \mathrm{kg}^{-1}\right)$ & 43 & 43 & 43 & 43 \\
\hline Sodium (Min.) $\left(\mathrm{g} \mathrm{kg}^{-1}\right)$ & 107 & 107 & 107 & 107 \\
\hline Sulfer (Min.) $\left(\mathrm{g} \mathrm{kg}^{-1}\right)$ & 12 & 12 & 12 & 12 \\
\hline Magnesium (Min.) (mg kg-1) & 5,000 & 5,000 & 5,000 & 5,000 \\
\hline Cobalt (Min.) (mg kg-1) & 150 & 150 & 150 & 150 \\
\hline Copper (Min.) (mg kg $\left.{ }^{-1}\right)$ & 1,500 & 1,500 & 1,500 & 1,500 \\
\hline Iodine (Min.) (mg kg-1) & 100 & 100 & 100 & 100 \\
\hline Manganese (Min.) $\left(\mathrm{mg} \mathrm{kg}^{-1}\right)$ & 780 & 780 & 780 & 780 \\
\hline Selenium (Min.) $\left(\mathrm{mg} \mathrm{kg}^{-1}\right)$ & 18 & 18 & 18 & 18 \\
\hline Zinc (Min.) $\left(\mathrm{mg} \mathrm{kg}^{-1}\right)$ & 0,000 & 2,000 & 4,000 & 6,000 \\
\hline Iron (Min.) (mg kg-1) & 800 & 800 & 800 & 800 \\
\hline Fluorine (Max.) (mg kg-1) & 430 & 430 & 430 & 430 \\
\hline Crude Protein (Min.) $\left(\mathrm{g} \mathrm{kg}^{-1}\right)$ & 180 & 180 & 180 & 180 \\
\hline NPN - Eq. Protein (Max.) $\left(\mathrm{g} \mathrm{kg}^{-1}\right)$ & 140 & 140 & 140 & 140 \\
\hline TDN (Mín.) $\left(\mathrm{g} \mathrm{kg}^{-1}\right)$ & 200 & 200 & 200 & 200 \\
\hline
\end{tabular}

$\mathrm{Zn}-0$, no addition of $\mathrm{Zn}$; Zn-2, with 2,000 mg of $\mathrm{Zn} \mathrm{kg}^{-1}$; Zn-4, with 4,000 mg of Zn kg-1; and Zn-6, with 6,000 mg of of Zn kg-1. ${ }^{1}$ Basic composition of the products: calcium carbonate, dicalcium phosphate, sodium chloride, ventilated sulfur, magnesium oxide, cobalt sulfate, copper sulfate, potassium iodide, manganese sulphate, sodium selenite, zinc sulphate, iron sulphate, livestock urea, soybean meal, corn, corn gluten.

$\mathrm{NPN}=$ non-protein nitrogen; $\mathrm{TDN}=$ total digestive nutrients. 
The animals were slaughtered at an average live weight of $570 \mathrm{~kg}$ after fasting for solid food for 16 hours, and weighed to allow subsequent determination of carcass yield.

All the animals were slaughtered at Frigorífico C. J. Comércio Ltda, located in the Presidente Prudente city, State of São Paulo. The stunning of the animals was performed with captive bolt gun for subsequent bleeding through the jugular vein section.

From each slaughtered animal were weighed: carcass, head, blood, liver, heart, kidneys, lung, tongue, leather, tail, esophagus, trachea and penis to evaluate the influence of different levels of $\mathrm{Zn}$ on absolute and relative weights of organs, viscera, carcasses and non-carcass components.

After slaughter, the carcasses were washed, identified and kept in a cold room for 24 hours at a temperature of 0 to $-2{ }^{\circ} \mathrm{C}$. The carcass yield (CY) was calculated using the equation: $\mathrm{CY}=$ (hot carcass weight/live weight) x 100 .

The carcass length was measured from each halfcarcass left, measured by the distance between the anterior border of the pubis and the medial anterior border of the first rib, and the width of the carcass measured by the distance from the lower border of the sternum to the lower edge of the carcass medulla between the fifth and the sixth dorsal vertebra, both with the aid of a tape measure.

Also, the leg length was measured by the distance between the midpoint of the tarsus-metatarsal joint and the anterior border of the ischium-pubic synthesis. The leg circumference was measured by wrapping it with a tape measure half its length.

The thickness of the thigh was obtained with the aid of a compass, obtaining the distance between the lateral and medial surfaces of the thigh.

After 24 hours of carcass chilling, the subcutaneous fat thickness (fat covering the Longissimus dorsi muscle) and loin eye area (LEA) were measured. With the aid of a pachymeter, the subcutaneous fat thickness was evaluated and by tracing the contour of Longissimus dorsi, on vellum, the loin eye area was determined. Both measurements were made between the $12^{\text {th }}$ and $13^{\text {th }}$ rib, according to the methodology described by USDA (1989).

From left half carcass, the cross section of the Longissimus dorsi including $9^{\text {th }}, 10^{\text {th }}$ and $11^{\text {th }}$ ribs (section H-H) was obtained. To determine the proportions of muscle, fat and bones, the proposed equations by Hankins and Howe (1946) were used: proportion of muscle: $\mathrm{y}=16.08+0.80 \mathrm{x}$; proportion of adipose tissue: $\mathrm{y}=3.54+0.80 \mathrm{x}$; proportion of bones: $\mathrm{y}=5.52+0.57 \mathrm{x}$, where $\mathrm{x}$ is the percentage of the component in section $\mathrm{H}-\mathrm{H}$.

For determination of lipid oxidation, samples of Longissimus dorsi were collected, identified, packed in polyethylene film and frozen at $-20^{\circ} \mathrm{C}$. The TBARS (lipid oxidation) analysis of meat was performed by the indicative of thiobarbituric acid reactive substances (TBARS), according to Crackel et al. (1988).

The $\mathrm{pH}$ of the meat was determined using a Hanna portable potentiometer equipped with a metal penetration electrode at $2 \mathrm{~cm}$ inside the Longissimus dorsi muscle after 24 hours of carcass cooling.

The meat color was determined in samples after 30 minutes of exposure to oxygen, for reaction of myoglobin with atmospheric oxygen, using the portable Minolta color colorimeter CR10, for evaluation of the components $L^{*}$ (luminosity), a* (red intensity -green) and $\mathrm{b}^{*}$ (yellow-blue intensity) by the CIELAB system (MINOLTA, 1998). The measurements were performed in three different regions, taking the mean as determined value.

Data were analyzed through analysis of variance and regression, using the procedure PROC GLM and PROC REG of the statistical analyzes system - SAS (2003). 


\section{Results and Discussion}

Productive performance and mineral supplement intake

The increasing inclusion of zinc in mineral supplementation of cattle did not affect $(\mathrm{P}>0.05)$ final body weight (FBW) and average daily weight gain (ADWG) (Table 3).
Brown et al. (2004) studied different sources and zinc contents in cattle, no significant differences on average daily weight gain (ADWG) were observed, although they noted that animals of control group (60 ppm $\mathrm{ZnSO}_{4}$ ) gained weight more rapidly, followed by animals of group receiving $90 \mathrm{ppm}$ $\mathrm{ZnSO}_{4}$ and lastly, those receiving 90 ppm ZnMet.

Table 3. Productive performance; mineral supplement intake containing different levels of zinc and inorganic zinc intake by the animals kept in pasture of Brachiaria brizantha cv. MG-4.

\begin{tabular}{|c|c|c|c|c|c|c|c|}
\hline \multirow[b]{2}{*}{ Variables } & \multicolumn{4}{|c|}{ Mineral Supplement ${ }^{1}$} & \multirow{2}{*}{$\mathrm{CV}(\%)$} & \multirow{2}{*}{$\operatorname{Pr}>F$} & \multirow{2}{*}{ Regression } \\
\hline & $\mathrm{Zn}-0$ & $\mathrm{Zn}-2$ & $\mathrm{Zn}-4$ & $\mathrm{Zn}-6$ & & & \\
\hline IBW, kg & 361.6 & 351.6 & 359.1 & 358.1 & 2.764 & 0.298 & $Y=357.62$ \\
\hline FBW, kg & 569.9 & 556.5 & 570.8 & 583.3 & 3.752 & 0.166 & $\mathrm{Y}=570.14$ \\
\hline ADWG, $\mathrm{kg}$ & 0.562 & 0.553 & 0.572 & 0.608 & 8.859 & 0.224 & $\mathrm{Y}=0.574$ \\
\hline MSI, g day ${ }^{-1}$ & 146 & 143 & 149 & 146 & 3.762 & 0.271 & $\mathrm{Y}=146$ \\
\hline ZnI, mg day ${ }^{-1}$ & 0 & 286 & 596 & 976 & 4.208 & 0.0001 & $\hat{Y}=-2.09386+146.9616 x ; R^{2}=0.99$ \\
\hline
\end{tabular}

${ }^{1} \mathrm{Zn}-0$, no addition of $\mathrm{Zn}$; Zn-2, with 2,000 mg of $\mathrm{Zn} \mathrm{kg}^{-1}$; Zn-4, with 4,000 mg of $\mathrm{Zn} \mathrm{kg}^{-1} \mathrm{e} \mathrm{Zn-6,} \mathrm{with} \mathrm{6,000} \mathrm{mg} \mathrm{of} \mathrm{Zn} \mathrm{kg-1;}$ IBW=Initial body weight; FBW= Final body weight; $\mathrm{ADWG}=$ average daily weight gain; $\mathrm{MSI}=$ average mineral supplement intake per animal per day; $\mathrm{ZnI}=$ average zinc intake per animal per day.

The final body weight and average daily weight gain obtained in this experiment were found to be similar to those reported by Malcom-Callis et al. (2000), when using levels of 20, 100 or $200 \mathrm{mg} \mathrm{Zn}$ $\mathrm{kg}^{-1} \mathrm{DM}$ in the feed of steers under confinement, as well as the results reported by Mullis et al. (2003).

It has also been observed in the literature that some researchers such as, Spears and Kegley (2002) and Mullis et al. (2003), evaluated the supply of different sources of zinc, organic and inorganic ( $\mathrm{ZnSO}_{4}$ and $\mathrm{ZnProt}, \mathrm{ZnO}$ ) to growing and finishing cattle, reporting no effect on dry matter intake, daily average weight gain, feed conversion and weight to slaughter.

There was no difference $(\mathrm{P}>0.05)$ in mineral supplement intake, confirming that zinc sulfate does not interfere with the acceptability of the mineral mixture, therefore, all animals ingested the same amount of the other minerals present in the formulations. On the other hand, there was difference $(\mathrm{P}<0.05)$ in zinc intake by the animals that received different levels of zinc supplementation.

It was found that the variables ADWG and FBW in animals receiving different levels of zinc in the supplementation (Zn-0, Zn of 2,000, 4,000 and 6,000

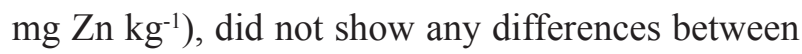
them, indicating that the supplementation of these levels of $\mathrm{Zn}$ does not influence the performance of beef cattle.

\section{Carcass traits}

The increase of zinc inclusions in the diet of cattle on pasture showed a positive linear effect $(\mathrm{P}<0.05)$ on the weight of hot carcasses, with averages of $310.53 \mathrm{~kg}$. Comparing the hot carcass weights of the animals receiving supplements $\mathrm{Zn}-0$ and $\mathrm{Zn}-6$, there was an increase of $6.86 \mathrm{~kg}$. Likely, 
increasing $\mathrm{Zn}$ levels in the mineral supplementation of animals improved growth hormone (GH) levels by modulating their secretion along the pituitary gland, which in turn stimulates the synthesis and secretion of insulin-like growth factor-1 (IGF1) through association with hepatic $\mathrm{GH}$ receptors, thus increasing the uptake of glucose and amino acids by the muscle fibers, thus promoting the muscular growth of the organism (GOMES; TIRAPEGUI, 1998).
The hot carcass yield (HCY) was not influenced $(\mathrm{P}>0.05)$ by the different levels of zinc in the supplementation (Table 4), because it was obtained from hot carcass weight relative to the live weight of the animals, which did not change with respect to the different supplements. According to Brondani et al. (2006), carcasses with lower amount of fat and greater amount of muscle are ideal, as it increases the carcass yield.

Table 4. Performance and carcass composition of cattle maintained on Brachiaria brizantha cv. MG-4, receiving mineral supplementation with different contents of zinc.

\begin{tabular}{|c|c|c|c|c|c|c|c|}
\hline \multirow{2}{*}{ Variables } & \multicolumn{4}{|c|}{ Mineral Supplement ${ }^{1}$} & \multirow{2}{*}{ CV $(\%)$} & \multirow{2}{*}{$\operatorname{Pr}>\mathrm{F}$} & \multirow{2}{*}{ Regression } \\
\hline & $\mathrm{Zn}-0$ & $\mathrm{Zn}-2$ & $\mathrm{Zn}-4$ & $\mathrm{Zn}-6$ & & & \\
\hline $\mathrm{HCW}, \mathrm{kg}$ & 305.14 & 301.28 & 314.71 & 312.00 & 4.22 & 0.038 & $\hat{Y}=299.92662+3.33362 x ; R^{2}=0.24$ \\
\hline $\mathrm{HCY}, \%$ & 53.54 & 54.15 & 55.16 & 55.02 & 2.68 & 0.154 & $\hat{\mathrm{Y}}=54.47$ \\
\hline Muscle, $\%$ & 62.37 & 63.49 & 63.47 & 64.11 & 4.59 & 0.73 & $\hat{\mathrm{Y}}=63.36$ \\
\hline Muscle, kg & 190.31 & 191.41 & 199.75 & 206.14 & 7.42 & 0.17 & $\hat{Y}=196.90$ \\
\hline Bone, \% & 13.84 & 13.73 & 13.17 & 13.40 & 6.13 & 0.43 & $\hat{\mathrm{Y}}=13.53$ \\
\hline Bone, $\mathrm{kg}$ & 42.18 & 41.37 & 41.46 & 42.99 & 7.22 & 0.73 & $\hat{Y}=42.00$ \\
\hline Fat, \% & 23.80 & 22.77 & 23.36 & 22.50 & 12.74 & 0.84 & $\hat{Y}=23.10$ \\
\hline Fat, kg & 72.65 & 68.51 & 73.50 & 71.87 & 12.39 & 0.74 & $\hat{Y}=71.63$ \\
\hline RMB & 4.51 & 4.64 & 4.84 & 4.81 & 7.87 & 0.33 & $\hat{\mathrm{Y}}=4.70$ \\
\hline $\mathrm{RMF}$ & 2.64 & 2.83 & 2.76 & 3.00 & 20.90 & 0.71 & $\hat{\mathrm{Y}}=2.81$ \\
\hline LEA, $\mathrm{cm}^{2}$ & 70.87 & 70.50 & 67.93 & 73.50 & 11.54 & 0.655 & $\hat{\mathrm{Y}}=70.70$ \\
\hline SCFT, mm & 6.00 & 5.71 & 8.57 & 7.00 & 38.45 & 0.195 & $\hat{\mathrm{Y}}=6.82$ \\
\hline
\end{tabular}

${ }^{1} \mathrm{Zn}-0$, no addition of $\mathrm{Zn}$; Zn-2, with 2,000 mg of Zn kg-1; Zn-4, with 4,000 mg of Zn kg-1 e Zn-6, with 6,000 mg of Zn kg Hot carcass weight; $\mathrm{HCY}=$ Hot carcass yield; RMB= Relationship Muscle:Bone; RMF= Relationship Muscle:Fat; LEA= Loin eye area; SCFT $=$ Subcutaneous fat thickness.

The physical composition of the carcasses (Table 4), obtained through the cut between the $9^{\text {th }}$ and $11^{\text {th }}$ ribs, showed no differences between animals in different supplements. The amount $(\mathrm{kg})$ and percentage of muscle, bone and fat in the carcass were also not influenced by the increasing inclusion of zinc in mineral supplementation.

The mean ( $\mathrm{kg}$ and \%) of muscle, bone and fat in the carcass were $196.9 \mathrm{~kg}$ and $63.36 \%$ (muscle), $42 \mathrm{~kg}$ and $13.53 \%$ (bone) and $71.63 \mathrm{~kg}$ and $23.10 \%$ (fat), respectively, and the relationships between muscle and bone was 4.70; and between muscle and fat, was 2.81 in carcass with a mean weight of $310.53 \mathrm{~kg}$.

These values are compatible with the percentages of muscle, bone and fat of Nellore breed, and resemble the results obtained by Vittori et al. (2006), who found values in the range of $61 \%$ for muscle yield, $15 \%$ for bone tissue yield and $24 \%$ for adipose tissue yield. Considering that the bone tissue is of early maturity, the small variation among terminating animals is justified. 
The loin eye area (LEA) and subcutaneous fat thickness (SCFT) measurements (Table 4) did not differ $(\mathrm{P}>0.05)$ among animals receiving supplements with different zinc contents. Berg and Butterfield (1976) have stated in their evaluations that in contemporary animals of the same breed no differences in LEA are expected.

The SCFT mean values reached $6.82 \mathrm{~mm}$, considered as uniform coverage. Only values of
SCFT of the animals receiving supplementation with 2,000 $\mathrm{mg} \mathrm{Zn} \mathrm{kg}^{-1}$ (Zn-2) presented values of $5.71 \mathrm{~mm}$, classified as median coverage, according to criteria adopted by Normative Instruction No. 9, of the Ministry of Livestock Agriculture and Supply (BRASIL, 2004).

There was no difference $(\mathrm{P}>0.05)$ for carcass traits of steers raised on pasture supplemented with different contents of zinc in this study (Table 5).

Table 5. Carcass traits of steers maintained on Brachiaria brizantha cv. MG-4, receiving mineral supplementation with different contents of zinc.

\begin{tabular}{|c|c|c|c|c|c|c|c|}
\hline \multirow{2}{*}{ Variables } & \multicolumn{4}{|c|}{ Mineral Supplement ${ }^{1}$} & \multirow{2}{*}{$\mathrm{CV}(\%)$} & \multirow{2}{*}{$\operatorname{Pr}>F$} & \multirow{2}{*}{ General average } \\
\hline & $\mathrm{Zn}-0$ & $\mathrm{Zn}-2$ & $\mathrm{Zn}-4$ & $\mathrm{Zn}-6$ & & & \\
\hline Fore, $\mathrm{kg}$ & 128.35 & 128.85 & 132.90 & 136.67 & 5.31 & 0.118 & 131.69 \\
\hline Fore, $\%$ & 22.54 & 23.16 & 23.31 & 23.40 & 4.95 & 0.504 & 23.10 \\
\hline Rear, kg & 177.93 & 173.92 & 182.14 & 184.71 & 5.11 & 0.162 & 179.67 \\
\hline Rear, $\%$ & 31.19 & 31.25 & 31.90 & 31.68 & 3.08 & 0.468 & 31.50 \\
\hline Carcass length, $\mathrm{cm}$ & 137.71 & 136.14 & 137.57 & 138.43 & 3.81 & 0.872 & 137.46 \\
\hline Carcass width, cm & 49.00 & 48.43 & 48.85 & 49.43 & 4.14 & 0.832 & 48.93 \\
\hline Leg length, cm & 95.07 & 93.64 & 95.85 & 93.50 & 2.72 & 0.273 & 94.51 \\
\hline Thigh Thickness, cm & 31.14 & 30.57 & 29.35 & 31.35 & 6.95 & 0.316 & 30.60 \\
\hline Thigh circumference, $\mathrm{cm}$ & 115.28 & 115.43 & 115.00 & 116.57 & 3.28 & 0.873 & 115.57 \\
\hline
\end{tabular}

${ }^{1} \mathrm{Zn}-0$, no addition of Zn; Zn-2, with 2,000 mg of Zn kg-1; Zn-4, with 4,000 mg of $\mathrm{Zn} \mathrm{kg}^{-1}$ e Zn-6, with 6,000 mg of $\mathrm{Zn} \mathrm{kg}^{-1}$.

Kabeya et al. (2002), studied the supply of different supplements for steers kept in pastures of Brachiaria brizantha cv. Marandu, and did not observe difference in carcass traits.

According to Rotta et al. (2009), the carcass traits such as weight and length of fore and rear, are little modified through nutritional management, being more influenced by different genetic groups.

The increasing inclusion of zinc in the mineral supplementation of pastured cattle, negatively influenced $(\mathrm{P}<0.05)$ the lipid oxidation values (Table 6 ), increasing the concentrations of malonaldehyde (mg TBARS $\mathrm{kg}^{-1}$ of sample) in the meat. These results contradict those of Garmyn et al. (2011) who observed a significant relationship, however low, between concentration of minerals, zinc on sulphate form and lipid oxidation, reporting that all of the minerals, except calcium and manganese were positively correlated $(\mathrm{P}<0.05)$ in samples of Longissimus dorsi of Angus cattle. 
Table 6. Lipid oxidation, color and $\mathrm{pH}$ in the meat of Nellore steers maintained in Brachiaria brizantha cv. MG-4 pasture, receiving mineral supplementation with different zinc contents.

\begin{tabular}{|c|c|c|c|c|c|c|c|}
\hline \multirow{2}{*}{ Variables } & \multicolumn{4}{|c|}{ Mineral Supplement $^{1}$} & \multirow{2}{*}{ CV $(\%)$} & \multirow{2}{*}{$\operatorname{Pr}>F$} & \multirow{2}{*}{ Regression } \\
\hline & Zn-0 & $\mathrm{Zn-2}$ & Zn-4 & Zn-6 & & & \\
\hline LO, mg & 0.155 & 0.190 & 0.269 & 0.289 & 34.59 & 0.01 & $\hat{Y}=0.15170+0.02539 x ; R^{2}=0.31$ \\
\hline$L$ & 31.89 & 32.16 & 35.14 & 33.88 & 6.13 & 0.02 & $\hat{Y}=32.23309+0.41445 x ; R^{2}=0.14$ \\
\hline$a$ & 18.63 & 18.22 & 24.11 & 22.28 & 13.69 & 0.001 & $\hat{\mathrm{Y}}=18.16225+0.88592 \mathrm{x} ; \mathrm{R}^{2}=0.25$ \\
\hline$b$ & 9.36 & 9.14 & 12.79 & 11.30 & 14.23 & 0.003 & $\hat{\mathrm{Y}}=9.35295+0.45030 \mathrm{x} ; \mathrm{R}^{2}=0.20$ \\
\hline $\mathrm{pH}$ & 5.68 & 5.65 & 5.56 & 5.60 & 1.59 & 0.112 & $\hat{\mathrm{Y}}=5.62$ \\
\hline
\end{tabular}

${ }^{1} \mathrm{Zn}-0$, no addition of $\mathrm{Zn}$; Zn-2, with 2,000 mg of $\mathrm{Zn} \mathrm{kg}^{-1}$; Zn-4, with 4,000 mg of Zn kg-1 e Zn-6, with 6,000 mg of Zn kg-1. $\mathrm{L}=$ luminosity; "a"= red-green intensity; "b"= yellow-blue intensity; $\mathrm{LO}=$ Lipid Oxidation express as mg of TBARS kg-1 of meat.

The increase in the concentrations of malonaldehyde probably occurred due to the fact that zinc is a structural component of the $\mathrm{Cu}$ ZnSOD enzyme, whose function is to catalyze the conversion of superoxides to hydrogen peroxide (potent pro-oxidant enzyme) promoting the disruption of the electrochemical barrier between the oxygen and molecules of unsaturated fatty acids, thus promoting lipid oxidation.

Esterbauer (1993) stated that zinc is the structural component of the enzyme superoxide dismutase, which in turn catalyzes the conversion of superoxide into potent pro-oxidant hydrogen peroxide. Although some minerals act as cofactors of antioxidant enzymes, certain microminerals such as zinc can also act as catalysts in lipid oxidation (AL-QUDAH et al., 2009).

The color variable, which gives the initial acceptability to the product, is perhaps the only tool for quality assessment that consumers use. $\mathrm{L}^{*}$ values are especially important for fresh beef, with higher values indicating paler meat $\left(\mathrm{L}^{*}=0\right.$ black, $\mathrm{L}^{*}=100$ white). To measure the validity of fresh meat on the shelf, the value of $\mathrm{a}^{*}$ becomes more important, and when they are higher, indicate more red meat.

The difference of color values in the meat from animals that received mineral supplements with different zinc contents was significant, but there are no studies that correlate zinc with the action of myoglobin, which may be related to the action of anabolic hormones such as GH and IGF-1, in addition to the interference of mitogenic hormones, which act on cell proliferation (SENA; PEDROSA, 2005).

Muchenje et al. (2009) reported that in cattle the average luminosity $\left(\mathrm{L}^{*}\right)$ varied between 33.2 and 41.0; the averages of red-green intensity color $\left(a^{*}\right)$ vary between 11.1 to 23.6 and the averages of yellow-blue intensity color $\left(b^{*}\right)$, vary between 6.1 and 11.3. In this work, the averages of $\mathrm{L}^{*}, \mathrm{a}^{*}$ and $\mathrm{b}^{*}$ remained within the values described by the authors, these limits being considered normal for beef.

There was no difference among the groups of animals that received different levels of zinc on $\mathrm{pH}$ values of the meat, and the average $\mathrm{pH}$ value found in this work was 5.62, characterizing a meat with good quality. Some factors such as nutritional status, temperament, transport and preslaughter management may influence the final $\mathrm{pH}$. Steers under stress in pre-slaughter management, promote reduction of muscle glycogen reserves ante-mortem. There is a reduction in lactate levels and an increase in post-mortem $\mathrm{pH}$, modifying the organoleptic characteristics of the meat, favoring the development of pathogenic microorganisms and bad smell. This reduces the shelf life of the meat (FERREIRA, 2006). 
There was no difference $(\mathrm{P}>0.05)$ in the relative and absolute weight of the variables: heart, tongue, kidneys, lung, trachea, liver, penis, head, leather and tail (Table 7). These results may be related to the similarity of the average final live weight and the carcasses yield that did not present differences in the animals receiving levels of zinc.

According to Peron et al. (1993), regardless of the level of feeding, the weights of some organs such as heart and lung are not affected, indicating that these organs maintain their integrity, as well as the weight of the head and tail, which are usually constant and their alteration is insignificant in relation to animals of the same weight and breed. This can be confirmed with the data obtained in this experiment, where the organ and visceral weights did not present statistical difference among the animals receiving supplements with different zinc contents.

Table 7. Absolute and relative weights of non-carcass components ( $\mathrm{kg}$ and \% of final live weight) of Nellore cattle maintained on Brachiaria brizantha cv. MG-4, receiving mineral supplementation with different zinc contents.

\begin{tabular}{|c|c|c|c|c|c|c|c|}
\hline \multirow{2}{*}{ Variables } & \multicolumn{4}{|c|}{ Mineral Supplement ${ }^{1}$} & \multirow{2}{*}{$\mathrm{CV}(\%)$} & \multirow{2}{*}{$\operatorname{Pr}>\mathrm{F}$} & \multirow{2}{*}{ General average } \\
\hline & $\mathrm{Zn}-0$ & $\mathrm{Zn}-2$ & $\mathrm{Zn}-4$ & $\mathrm{Zn}-6$ & & & \\
\hline Heart, kg & 1.64 & 1.69 & 1.72 & 1.70 & 10.59 & 0.852 & 1.68 \\
\hline Heart, \% & 0.28 & 0.30 & 0.30 & 0.29 & 9.74 & 0.621 & 0.29 \\
\hline Tongue, $\mathrm{kg}$ & 3.89 & 3.70 & 3.93 & 3.70 & 7.35 & 0.296 & 3.81 \\
\hline Tongue, $\%$ & 0.68 & 0.66 & 0.68 & 0.63 & 7.28 & 0.181 & 0.66 \\
\hline Kidney, kg & 0.68 & 0.91 & 0.92 & 0.85 & 23.58 & 0.183 & 0.85 \\
\hline Kidney, \% & 0.12 & 0.16 & 0.16 & 0.14 & 22.18 & 0.124 & 0.14 \\
\hline Lung, kg & 3.41 & 3.45 & 2.92 & 3.08 & 15.22 & 0.147 & 3.21 \\
\hline Lung, \% & 0.60 & 0.62 & 0.51 & 0.52 & 14.65 & 0.555 & 0.56 \\
\hline Trachea, kg & 0.82 & 0.72 & 0.96 & 1.09 & 27.06 & 0.053 & 0.90 \\
\hline Trachea, \% & 0.14 & 0.13 & 0.17 & 0.18 & 26.29 & 0.084 & 0.15 \\
\hline Liver, kg & 5.52 & 6.01 & 6.05 & 6.17 & 10.67 & 0.258 & 5.93 \\
\hline Liver, \% & 0.97 & 1.08 & 1.06 & 1.05 & 11.01 & 0.305 & 1.04 \\
\hline Penis, kg & 0.62 & 0.75 & 0.67 & 0.72 & 15.74 & 0.175 & 0.70 \\
\hline Penis, \% & 0.11 & 0.13 & 0.11 & 0.12 & 16.31 & 0.110 & 0.12 \\
\hline Head, kg & 9.60 & 9.45 & 10.42 & 9.71 & 7.32 & 0.080 & 9.80 \\
\hline Head, \% & 1.68 & 1.70 & 1.82 & 1.66 & 6.76 & 0.071 & 1.71 \\
\hline Leather, kg & 51.91 & 47.57 & 51.20 & 48.82 & 12.59 & 0.544 & 49.87 \\
\hline Leather, \% & 9.09 & 8.55 & 8.97 & 8.37 & 11.91 & 0.534 & 8.75 \\
\hline Tail, kg & 1.55 & 1.43 & 1.60 & 1.43 & 11.41 & 0.190 & 1.50 \\
\hline Tail, \% & 0.27 & 0.25 & 0.28 & 0.24 & 10.16 & 0.118 & 0.26 \\
\hline
\end{tabular}

${ }^{1} \mathrm{Zn}-0$, no addition of $\mathrm{Zn}$; Zn-2, with $2.000 \mathrm{mg}$ of $\mathrm{Zn} \mathrm{kg}^{-1}$; Zn-4, with $4.000 \mathrm{mg}$ of $\mathrm{Zn} \mathrm{kg}{ }^{-1} \mathrm{e} \mathrm{Zn}-6$, with $6.000 \mathrm{mg}$ of $\mathrm{Zn} \mathrm{kg}^{-1}$. 


\section{Conclusion}

Nellore steers, finishing on Brachiaria brizantha cv. MG-4 and supplemented with increasing zinc contents, presented linear increases in hot carcass weight, without causing an increase in organ and viscera weight.

Increasing levels of zinc in the mineral supplement did not affect carcass yield, weight gain and carcass physical composition of steers finished in pasture.

Supplementation with increasing zinc levels, increases the malonaldehyde (TBARS) concentrations, indicating a higher oxidative action in meats of Nellore steers finished on pasture.

\section{References}

AL-QUDAH, K. M.; GHARAIBEH, A. A.; ALSHYYAB, M. M. Trace minerals status and antioxidant activities in calves with Dermatophyosis. Biological Trace Element Research, Clifton, v. 136, n. 1, p. 40-47, 2009.

ASSOCIATION OF OFFICIAL ANALYTICAL CHEMISTS - AOAC. Official methods of analysis. $15^{\text {th }}$ ed. Arlington: Edited by Kenneth Helrich, 1990. v. 1-2, $1298 \mathrm{p}$.

BERG, R. T.; BUTTERFIELD, R. M. New concepts of cattle growth. Sidney: Sidney University, 1976. 240 p.

BRASIL. Ministério da Agricultura, Pecuária e Abastecimento. Instrução Normativa $\mathrm{N}^{\circ} 9$, de 4 de maio de 2004. Sistema brasileiro de classificação de carcaças de bovinos. Diário Oficial [da] República Federativa do Brasil, Brasília, 05 maio 2004, Seção 1, p. 1-5.

BRONDANI, I. L.; RESTLE, J.; ARBOITTE, M. Z.; MENEZES, L. F. G.; ALVES FILHO, D. C.; AMARAL, G. A.; PAZDIORA, R. D. Efeito de dietas que contêm cana de-açúcar ou silagem de milho sobre as características das carcaças de novilhos confinados. Ciência Rural, Santa Maria, v. 36, n. 1, p. 197-202, 2006.

BROWN, M. S.; CHOCHRAN, E. M.; DRAGER, C. D. Influence of zinc on feedlot performance and carcass characteristics of steers. Beef Cattle Research in Texas. Department of Animal Science, Texas A\&M University System, College Station, TX. 2004. p. 105-108.

CARVALHO, F. A. N.; BARBOSA, F. A.; McDOWELL, L. R. Nutrição de bovinos a pasto. 2. ed. Belo Horizonte:
PapelForm, 2005. 428 p.

CRACKEL, R. L.; GRAY, I. J.; PEARSON, A. M.; BOOREN, A. M.; BUCKLEY, O. J. Some further observations on the TBA test as an index of lipid oxidation in meats. Food Chemistry, Kindlington, v. 28, n. 3, p. 187-196, 1988.

CRUZ, J. B. F.; SOARES, H. F. Uma revisão sobre zinco. Ensaios e Ciência: Ciências Biológicas, Agrárias e da Saúde, Valinhos, v. 15, n. 1, p. 208-222, 2011.

ESTERBAUER, H. Cytotoxicity and genotoxicity of lipid-oxidation products. American Journal of Clinical Nutrition, Bethesda, v. 57, n. 5, p. S779-S786, 1993.

EUCLIDES FILHO, K.; EUCLIDES, V. P. B. Desenvolvimento recente da pecuária de corte brasileira e suas perspectivas. In: PIRES, A. V. Bovinocultura de corte. Piracicaba: FEALQ, 2010. v. 1, p. 11-40,

FERREIRA, J. J. Desempenho e comportamento ingestivo de novilhos e vacas sob frequências de alimentação em confinamento. 2006. Dissertação (Mestrado em Zootecnia) - Universidade Federal de Santa Maria, Santa Maria.

GARMYN, A. J.; HILTON, G. G.; MATEESCU, R. G.; MORGAN, J. B.; REECY, J. M.; TAIT JUNIOR, R. G.; BEITZ, D. C.; DUAN, Q.; SCHOONMAKER, J. P.; MAYES, M. S.; DREWNOSKI, M. E.; LUI, Q.; VANOVERBEKE, D. L. Estimation of relationships between mineral concentration and fatty acid composition of longissimus muscle and beef palatability traits. Journal of Animal Science, Champaign, v. 89 n. 9, p. 2849-2858, 2011.

GOMES, M. R.; TIRAPEGUI, J. Relação entre o fator de crescimento semelhante a insulin (IGF-1) e atividade física. Revista Brasileira de Atividade Física e Saúde, Pelotas, v. 3, n. 4, p. 66-76, 1998.

HANKINS, O. G.; HOWE, P. E. Estimation of the composition of beef carcasses and cuts. Washington: United Sates Department of Agriculture, 1946. 20 p. (Technical Bulletin - USDA, 926).

KABEYA, K. S.; PAULINO, M. F.; DETMANN, E.; VALADARES FILHO, S. C.; CECON, P. R.; QUEIROZ, D. S.; GOMES JUNIOR, P.; PEREIRA, O. G. Suplementação de novilhos mestiços em pastejo na época de transição água-seca: desempenho produtivo, características físicas de carcaça, consumo e parâmetros ruminais. Revista Brasileira de Zootecnia, Viçosa, MG, v. 31, n. 1, p. 213-222, 2002.

LEHNINGER, A. L.; NELSON, D. L.; COX, M. M. Princípios de bioquímica. 4. ed. São Paulo: Sarvier, 2006. $1202 \mathrm{p}$. 
MALCOM-CALLIS, K. J.; DUFF, G. C.; GUNTER, S. A.; KEGLEY, E. B.; VERMEIRE, D. A. Effects of supplemetal zinc concentration and source on performance, carcass characteristics, and serum values in finishing beef steers. Journal of Animal Science, Champaign, v. 78, n. 11, p. 2801-2808, 2000.

McDOWELL, L. R.; CONRAD, J. H.; HARRIS, L. E.; THOMAS, J. E. Tabelas de composição de alimentos da América Latina. Gainesville: Universidade da Flórida, 1974. $47 \mathrm{p}$.

MINOLTA. Precise color communication - color control from perception to instrumentation. Osaka, 1998. 59 p.

MIZUBUTI, I. Y.; PINTO, A. P. P.; RAMOS, B. M. O.; PEREIRA, E. S. Métodos laboratoriais de avaliação de alimentos para animais. Londrina: EDUEL, 2009. 228 p.

MORAES, S. S. Principais deficiências minerais em bovinos de corte. Campo Grande: EMBRAPA, 2001. 27 p. (Documento, 112).

MUCHENJE, V.; DZAMAC, B. K.; CHIMONYOA, M.; STRYDOM, P. E.; HUGO, A.; RAATS, J. G. Some biochemical aspects pertaining to beef eating quality and consumer health: a review. Food Chemistry, Kindlington, v. 112, n. 2, p. 279-289, 2009.

MULLIS, L. A.; SPEARS, J. W.; MCCRAW, R. L. Effects of breed (Angus vs Simmental) and copper and zinc source on mineral status of steers fed high dietary iron. Journal of Animal Science, Champaign, v. 81, n. 1, p. 318-322, 2003.

NATIONAL RESEARCH COUNCIL - NRC. Nutrient requirements of beef cattle. $7^{\text {th }}$ rev. ed. Washington: National Academy Press, 2000. 248 p.

ORTOLANI, E. L.; SUCUPIRA, M. C. A. Deficiências macro e microelementos em gado de corte. In bovinocultura de corte. Piracicaba: FEALQ, 2010. v. 1, $760 \mathrm{p}$.

PERON, A. J.; FONTES, C. A. A.; LANA, R. P.; SILVA, D. J.; QUEIROZ, A. C.; PAULINO, M. Tamanho de órgãos internos e distribuição da gordura corporal em novilhos de cinco grupos genéticos submetidos à alimentação restrita e ad libitum. Revista da Sociedade Brasileira de Zootecnia, Viçosa, MG, v. 22, n. 5, p. 813819, 1993.
ROTTA, P.P.; PRADO, I. N.; PRADO, R. M.; MOLETTA, J. L.; SILVA, R. R.; PEROTTO, D. Carcass characteristics and chemical composition of the Longissimus muscle of Nellore, Caracu and Holstein-friesian bulls finished in feedlot. Asian- Australasian Journal Animal Science, Seoul, v. 22, n. 4, p. 598-604, 2009.

SALGUEIRO, J.; ZUBILLAGA, M.; LYSIONEK, A.; SARABIA, M. I.; CARO, R.; PAOLI, T. Cinc: conceptos actuales sobre un micronutriente esencial. Acta Physiology, Pharmacology et Therapeutica Latinoamerica, Buenos Aires, v. 49, n. 1, p. 1-12, 1999.

SENA, K. C. M.; PEDROSA, L. F. C. Efeitos da suplementação com zinco sobre o crescimento, sistema imunológico e diabetes. Revista de Nutrição, Campinas, v. 18, n. 2, p. 251-259, 2005.

SILVA, S.; BARUSELLI, M. S. Os dez mandamentos da suplementação mineral. Guaíba: Ed. Agropecuária Ltda, 2001. $106 \mathrm{p}$.

SPEARS, J. W.; KEGLEY, E. B. Effect of zinc (source oxide vs zinc proteinate) and level on performance, carcass characteristics, and immune response of growing and finishing steers. Journal of Animal Science, Champaign, v. 80, n. 10, p. 2747-2752, 2002.

STATISTICAL ANALYSIS SYSTEM - SAS. SAS system for windows: version 9.1.3. Cary: SAS Institute Inc., 2003.

U.S. DEPARTMENT OF AGRICULTURE - USDA. Official United States standards for grades of carcass beef. Washington: USDA, Agric. Marketing Serv., 1989.

VÁZQUEZ-AÑÓN, M.; NOCEK, J.; BOWMAN, G.; HAMPTON, T.; ATWELL, C.; VAZQUEZ, P.; JENKINS, T. Effects of feeding a dietary antioxidant in diets with oxidized fat on lactation performance and antioxidant status of the cow. Journal of Dairy Science, Madison, v. 91, n. 8, p. 3165-3172, 2008.

VITTORI, A.; QUEIROZ, A. C.; RESENDE, F. D.; GESUALDI, A. J.; ALLEONI, G. F.; RAZOOK, A. G.; FIGUEIREDO, L. A.; GESUALDI, A. C. L. S. Características de carcaça de bovinos de diferentes grupos genéticos, castrados e não-castrados, em fase de terminação. Revista Brasileira de Zootecnia, Viçosa, MG, v. 35, n. 5, p. 2085-2092, 2006. 
